\title{
A Comparative Study of "Self Knowing" from the Viewpoint of Rumi and Shankara
}

\section{Afroogh MR* \\ Azad University, Iran}

*Corresponding author: Mohammad reza Afroogh (PhD in Comparative religions and Mysticism), Azad University, Iran, Tel: 09337745226; Email: afroogh100@yahoo.com

\section{Research article \\ Volume 2 Issue 1}

Received Date: January 25, 2019

Published Date: March 04, 2019

DOI: $10.23880 /$ phij-16000115

\section{Abstract}

The mystics always have a special interest in human beings. They think about both human being and his ideas, that is, in their thinking anthropology is of great importance from various dimensions especially epistemological, ethical and social. Therefore, the drawing and explanation of the features of the mystical man is a concern. They are for the sake of man and his greatness. Of course, it should be noted that their attitude towards humans is more than moral and moral dimension, and other aspects of anthropology, practical action, have a special place in his thought. This attitude towards man by him is the epistemic existential dimensions, as well as the nature of human truth, and in particular, the perfect man's attributes Includes. In this article, we use the views and opinions of these two great mystics and their interpretation based on their literary texts to study the role and effect of self-knowledge as a great and common way between the two mystics for connecting to the Absolute Truth. The present study is a descriptive comparative study and data are analyzed and analyzed using a content analysis method in a library method.

Keywords: Self; Self-knowledge; Knowledge; Love; Human

\section{Introduction}

Although the two great mystics of Islam and Hinduism (Rumi and Shankara) have separate origins and developed in a different cultural atmosphere and their teachings are in some ways different from each other, they have also been very similar. This affinity and similarity can be seen in their mysticism. Due to the similarities and similarities between the Hindu school and the Masnavi, the study of the issue of unity between man and God is of particular importance in both schools. . Vedanta is the most complete and most mundane Hindu school that represents the teachings of the Upanishads and is based on the theory of the unity of existence and the main points raised in it are attention to the ultimate and divine truth. Shankara, as one of the great scholars and commentators of this school of aspirations the monotheism expanded the Upanishads and established the beliefs of Brahmasotra and considered the basis of all the realities of the world as Brahman. (India's Philosophical Religions and Schools, 2-781). In his view, Brahman's knowledge is to discover the pure analogy of Atman and Brahman, and the infinite Brahman comes from the illusion of relativity, and to the fourfold, the awakening world, the dream world, for example, the deep sleep world and his attitude to Atman. These determinations in the world of minerals are in the form of five determinations, namely, the corners of the food, the 


\section{Philosophy International Journal}

cornerstone, the cortex of the mind and the cortex and they create a hide that prevents everyone from seeing the inner light. This ignorance and ignorance in the great world appear as a force in the world and in the world of illusion and in the world of knowledge as ignorance and ignorance. (Ibid, 6-785). In Islamic mysticism, Rumi, in his works, addresses the issue of God and soul and importance an affiliate and a lover and lover alliance.

Rumi has a special interest in man. He also contemplates the existence of man and his thoughts, that is, in the words of Rumi, anthropology is of great importance from various dimensions especially epistemological, ethical and social. Therefore, the drawing and explanation of the features of the mystical man indicates the concern of Rumi To the human being and to the greatness of his being. Of course, it should be noted that Rumi's attitude towards man is more than the mystical and creative aspect, so that theoretical mysticism, practical action is a special place in his thought that this attitude toward man by him manifests the epistemic existential dimensions as well as the nature of human truth and, in particular, the perfect man's attributes has.

In Rumi's view, human being consists of two truths of the body and soul or soul, each of which has its own specific characteristics. The physical aspect of his resemblance and proximity to nature and the animal itself, while his spiritual dimension shows the high spiritual tendencies in him, suggests that man has moved from this land to this earthly and material world, And away from the original home, he pays special attention to the greatness of man in the creation of all its dimensions and makes him the essence. The abstract of the universe and the universe knows that other beings, as attributes and traits, are toward him.

Shankara considers man as a creature that is superior to all creatures because the whole intellect is in man, as well as the human being who speaks and sees based on thoughts and tells the future and understands many things, and surrounded the environment and is superior to all realms of being. Human being is the only one that manifested in the complete manifestation of God in him. Additionally, man is an individual whose complete manifestation of God has come to pass. In addition, man is an organism whose constructive thought $\mathrm{He}$ is, in the words "Whoever thinks he becomes the same is forever".

From the point of view of the Upanishads in man, a person called Atman, which is a manifestation of the universal soul or Brahman, that "the whole soul is the same individual and the same creation" (ibid., 379) is also the human being who aspires to his perfection and always must pay attention to his ambition And he does not neglect him because he neglects humanity's perfection. Atma is more than anything else for human beings. From child and property, and from everything else, should be considered more lovable. Therefore, human beings have considered a human having two physical and immaterial realms, which have a spirit and a body, and consists of "Joe Atman" is himself the perm Atman of himself, the cosmic or general, which Jive Atman enjoys from the result of the act, and Perm Atman is an observer of actions, and they have two shades of certainty (31-kath: 6.4svet.up).

Also, for the understanding of Atman, the human body and its organs are brought as allegories (brhad.up2.2-1-4), and the difference between the object and Atman is mentioned, that the body of life is the place of Atman, and Atman belongs to the object But after leaving it, it abandons.

\section{The Basics of Mysticism in Rumi's View}

The basis of the attitude of Muslim mystics to the world is accepted by the Qur'anic teachings. God has repeatedly emphasized in the Holy Qur'an that you should study in the earth, learn the lessons of the ancestors (Anam/ 11) and learn about the quality of creation. (Spider, Verse: 20) God revealed His Signs and Verses in horizons of the world and souls, (Foselat/ 53), and the human being sees it as the other side.

Rumi was aware of the fact that there is no distance between this world and the hereafter. This world is in that world and that world is also the environment in this world. We also, if we know how this world is, we will find that the world is in the hereafter, and there is not only hostility between the world and the hereafter, but also in terms of friendship and background and participation in the unity. Rumi, who knew the seven cities of love and who was familiar with the geography of the world of spirituality, sees no geographical boundaries between the world and the hereafter, and says:

The world is all over the world. It is about the mysticism of the world. It is a happy world.

Rumi's world is not the world of despair and grief that is at the forefront of Khayyami, which does not look beyond the senses of the world, nor the cold and impoverished climate of the monastery, who does not feel the world. Zarrin Kob (p. 15), not a world full of persecution and violence, nor a small and sensible area of 


\section{Philosophy International Journal}

knowledge and experience, a wavy irritation that sweeps through its passion, freshness, meaning and life, and Life is a long road with a joyous song that humans sing and love throughout.

Such a world "is merely to be experienced and felt, not to be described". Therefore, it is only those who find that the context is they have put together a couch with Rumi in his life so that he can fly along with him in his world, and Rumi's speech is the only invitation from these people.

Rumi never misses the world and despises the universe, and does not deny the earth. In his view, what condemns the name of the world, or, to put it more correctly, the humble world is the same greed, and in not finding the truth. In this regard, the world is a concept that changes to the value of everyone and, from the one who has not gained the truth, this world is a ghost. Goppinari (p. 274), as it says:

0 mouth of your own infernal crust!

The other light of the world of the milk of the blood of the blood Pahlavi.

It turns out that the shameless world in terms of hair loss is a world that does not bring a man to social calm and does not provide him with a secure future and does not lead him to a vital life free from bruises and full of inner affluence. The world is captured by the fork of greed, and unassigned to the eternal ecstasy, a zone that overcomes the spiritual calm of humans and reduces man from a high human condition, to the point where everyone thinks of his personal and personal interests. . It is a place where greed is driven by the command and is an inspirational range, with conditions that create greed.

\section{The Basics of Mysticism in Shankara's View}

Shankara is a thinker of existential unity, and Brahman, Atman, and the unity between them form the basis of his intellectual system. He expanded and promoted the uniqueness of the Upanishads, and organized the ideas and votes of the Prophet. The inviolable boundary of all the realities of the world is called Brahman, that is, the principle of neutrality which, in the dimension of transcendence and its literal aspect, does not have any attribute, and can only be expressed in the essence of the universe, I believe that being is mere and beyond the subjective and objective determinations of Atman Atman and Brahman are two poles of reality in the great and minor universe, and according to Vedanta, "Brahman is real, the mortal world is the soul of the same Atman is not enough."
The universe has been added to Brahman. And if we remove all manifestations and limitations from the text of the facts and abstraction, what remains is the absolute reality that remains and radiates on itself. In their view, Brahman's knowledge of the secrecy of pure adherence Atman and Brahman, the reality of the world can be summed up in this brief equation, namely, "Atman is equal to Berahman." Therefore, the religion of Vedanta says Shankara is a religion of complete dishonesty and lack of plurality.

Shankara never accepted the principle of the plurality of ghosts, and according to him, Amman is not the result of the accumulation of all personal spirits, but an entirely unassailable and spiritual entity that is neither subject nor passive and is not confined to consciousness and integrity, but absolute observer and witness Like Brahman, and in terms like "you are the same", the phrase "you are the same" indicates that if you include the adjectives that come into the word "you" and depict it as something other than that "You "will mean" Atman "of the same" it ", ie" Brahman ", because these two facts are two mirror-shaped faces.

According to Shankar, the soul and God are absolutely and similar. The soul is God and Allah the same being that they say this unity.

\section{The Position of Self-knowledge in Rumi's Anthropology}

Self-knowledge in Islam and in the case of the Muslim mystics as the encyclopedia, Rumi emphasized the importance of this issue by referring to a well-known Saying from Imam Ali (AS), which stated: "Everyone who knows himself knows his Lord, undoubtedly" Has given Of course, we know that the evolution of the world is conditional on the evolution of the universe and reaching the worker is the culmination of human evolution, and this issue is not possible without self-knowledge. That's why no knowledge is as important as self-knowledge.

In this regard, Rumi says: "A man is something great, everything is written in him, and he does not allow Cover and darkness that he reads that science in the veil and the darkness of these various occupations." In addition, selfknowledge, apart from its intrinsic value, is of special significance because of the lack of knowledge of theology and the knowledge of the god-fearing God. According to Rumi, he says:

For this, the Prophet created this description for anyone who knew himself, knows his Lord 


\section{Philosophy International Journal}

Mathnavi (5/2114) With this citation, Rumi reminds us that the necessity of recognizing and the inner paths is that the true self of man is the manifestation of the divine right and that this will not be realized until the person chooses to do so. In his view, in the spirit of the nursery and behind you, in the human soul, there are emotions and emotions and mysterious powers that human beings are unaware of, but the effect and sign of the inner forces and forces of mankind are manifest in man's actions and behavior. Round, In his prose book, the significance of this kind of noble science and knowledge is as follows: "Now also the scholars of the time split in hair and other things that they do not belong to, and they are surrounded by them in general, and what is important and $\mathrm{He}$ is the closest of all, he is an insider and does not know his own". Also, in the Rumi universe, none of human science and education has the value and importance of self-knowledge.

With this citation, Rumi reminds us that the necessity of recognizing and the inner paths is that the true self of man is the manifestation of the divine right, and that this will not be realized until the person chooses to do so. In his view, in the spirit of the nursery and behind you, in the human soul, there are emotions and emotions and mysterious powers that human beings are unaware of, but the effect and sign of the inner forces and forces of mankind are manifest in man's actions and behavior. Round, in his prose book, the significance of this kind of noble science and knowledge is as follows: "Now also the scholars of the time split in hair and other things that they do not belong to, and they are surrounded by them in general, and what is important and He is the closest of all, he is an insider and does not know his own". Also, in the Rumi universe, none of human science and education has the value and importance of self-knowledge.

If you think your thoughts are good, you're cool. If you do not think, You are nothing, Masnavi (2781388/2).

The importance of the self-knowledge of the teachings is also that it perceives and manages the human being, and also the insight can help human beings in the course of evolution, because in this way, he will perceive this insight and consciousness even the beings who can become available. In fact, the value of self-knowledge becomes apparent when it comes to finding one's self and knowing that it is hidden under this flesh and the skin, and it is the purpose of the creation, that it is the cloak in which it can manifest all being.

Its appearance is a mosquito flour to the wheel, its interior is a seven-wheel environment.
Intact solar hidden in a particle, male lion in a bumper sheath Sunny in one hidden particle, suddenly open that particle mouth The scientific field is not hidden, it is hidden in three tastes of the world.

If a man knows that right has manifested himself, he will seek his discovery because God created him for this reason. Because the meaning of Great Lord was in manifestation and appearance, So the Caliph was the owner of the throne, so that his king was a mirror Then he gave him an empty robe, and he asked for his darkness.

The most important thing that mankind gives to man is knowing the heart or soul in which he has chosen a god with all glory and abundance (the inquiry of $1387 / 6 / 3317)$.

Therefore, in Rumii's thought, this fact is repeated every time, and it turns out that until a person recognizes his identity and identity, he will not be able to understand the true social life of religion and prosperity. Selfawareness is the most important human-centered issue of religion. In addition, Rumi says that humans tend to feel so self-righteous that his interpretation of the rank of the great sultan who can be the essence of the creatures of the universe is a complex expression.

\section{The position of self-knowledge in the anthropology of the Sankara}

Self-knowledge and knowledge of the soul are one of the main sources of God's knowledge and have always been considered in mystical systems. Of course, this is not the coordinates of Islamic mysticism, but in fact, in most of the mystical religious systems there can be traced back to it. Among Hindu thinkers, Ara Shankara is a thinker and a great commentator of the Vedanta, and since he is a moderated school of dualism. The connection between the human soul with the original origin and the emphasis on its uniqueness is one of the fundamental determinations of the foundations of the mystical system. The most important factor in the unity of Atman and Brahman in the school is to learn the truth of the truth, and the existence of Brahman is the fact that we call it "self" or "pronoun", because every creature is selfconscious as "I am" So Brahman is the origin of the universe, which is exported from all beings, and is a joke of our existence, which we say to Atman, whoever knows the truth about the truth, has realized the truth of the truth, and everyone who knows the Brahman, that is, the inward insistence He has realized that "I am indeed a Brahman". 


\section{Philosophy International Journal}

Therefore, the unity of Atman (soul) and Brahman in the school of Vedanta, which is regarded as one of the most important teachings, can in fact be translated as "the true self of man, it is God." Based on this, Brahman is the truth, and in Inside us, the sacrifices of the Vedas and the rituals that are performed with it are superfluous and even meaningless to reach the purpose of the way of karma or of the acts of men, but through the knowledge of oneself, and the true sacrifice is also to sacrifice all of you and to abandon "I ".

\section{Compare and Conclusion}

The mystical approach to self-knowledge is one of the most important issues that makes the mystics distinct from others, especially philosophers and theologians, although the ultimate goal is the mystic of the knowledge of the Lord, but from the point of view of the mystics, the only way, or at least the most correct way of knowing, is self-knowledge (Unity of existence, narrated by Ibn Arabi and Eckhart, 279) is a view we do not think about it, but it is the path to reaching that intuition, and this is said by the Prophet (s), that whoever knows himself, God Knows. Everything is from you and in you. There is nothing outside of you.

If we consider the most important goal in the mysticism of alliance and the connection of man to God, this matter has been reflected in the school of Islam and Shahnara and Masnavi Rumi. By comparing these two schools, we can look at similarities and differences in the issue. One of the similarities of these two schools is the attention to the problem of repentance, which corresponds to human excellence and the connection to the absolute truth. The importance of self-knowledge and the progression of anxiety to achieve the connection between the soul and God in this regard is very important in both schools, too.

In addition, there are similarities between the two schools in terms of the existence of obstacles to connecting and joining the Lord, because in both schools, eliminating ignorance and relying not on the apparent knowledge or on Evydia, the avoidance of illusion or Maya and the avoidance of diseases Ethical, has been emphasized. However, similarities can be seen between the two schools. Among them, one can imagine love, which is not mentioned in the school of love as one of the sure ways to achieve the unity of Atman and Brahman. While in Rumi's view, ultimate divine love is to reach the level of unity and unity. This love is so passionate that it is incapable of describing it. Also, what separates human beings from one's own self and gives them the right to survive is love that eliminates itself in the presence of mankind, and removes God's Masnavi from the path of the right and leaves the way for the smooth seamstress makes the difficulty easy and tough. And in the light of evolution and transformation, man becomes empty to him and becomes self-destructive and, with his own power, possesses divine traits, survives to the truth and endures immortality.

\section{References}

1. Dasgupta S (1955) A History of Indian Philosophy. Motilal Banarsidass Publishers, Delhi.

2. Barth A (2000) The Religions of India. Roultedge.

3. Michei Myers (2001) Brahman, comparative theology Curzon.

4. Chander SC, Drinda D (1384) Introducing Indian philosophy schools. University press, Qum.

5. Cyprian S (1993) Meister Eckhart on Union of Man with God. In: Herrera RA (Ed.), Mystics or the Books. New York, Peter Lang Publishing.

6. Dara Shokoh, Mohammad, Upanishads Translation, Elmi Pub. Tehran 1388.

7. Dasgupta S (1955) A History of Indian Philosophy. Motilal Banarsidass Publishers, Delhi.

8. Dasgupta S (1959) Hindu Mysticism. USA.

9. Ebn Arabi Mohidin (1404) Footohatol Makya. Dare Sader publishing, Biroot.

10. Foroozan far B (1381) Masnavi stories. Amir Kabir Publishing, Tehran.

11. Dasgupta S (1959) Hindu Mysticism. USA.

12. Hiriyanna M (1993) Outlines of Indian Philosophy. Motilal, Delhi.

13. Ninan S (1967) Indian Philosophy, the Encyclopedia of Philosophy. Paul E (Ed.), Macmillan Company, New York.

14. Radhakrishnan S (1991) Indian Philosophy. 1\&2 (Vol), oxford University Press, Oxford.

15. Radhakrishnan S (1997) Introduction on the Principall Upanisads; Harpcollins, Noida,5ad cmpression, India. 


\section{Philosophy International Journal}

16. Navlakha S (2000) Introduction to Upanishad, Wordsworth Classics pf World Litrature.

17. James $W(1985)$ The varieties of religious experience. Modern library Inc, New York.

18. Mahmoodi A (1392) East in two horizons. University press. Qum.

19. Meister Eckhart (1993) Union of Man with God Smith, Cyprian. In: Herrera RA (Ed.), Mystics or the Books, New York, Peter Lang Publishing.

20. Myers M Brahman (2001) Comparative theology Curzon.

21. (1994) Mystical Languages of Unsaying, Sells, Michael, Chicago, The University of Chicago Press,

22. (1976) Mysticism East and West, Otto, Rudolf, A Comparative Analysis of the Nature of Mysticism, Trasl. by Bertha L. Brancy and Richenda C. Pane, New York, Macmillan Publishing Co.

23. G Parrinder (1976) Mysticism in the world's Religions.

24. Navlakha S (2000) Introduction to Upanishad, Wordsworth Classics pf World Litrature.

25. Otto R (1976) Mysticism East and West. A Comparative Analysis of the Nature of Mysticism, Trasl. by Bertha L. Brancy and Richenda C. Pane, New York, Macmillan Publishing Co

26. Hiriyanna M (1993) Outlines of Indian Philosophy. Motilal, Delhi.

27. Parrinder G (1976) Mysticism in the world. Religions pub.
28. Radhakrishnan S (1991) Indian Philosophy.oxford University Press, Oxford.

29. Radhakrishnan S (1994) The Principal upanisads. Edited with Introduction text. Humunitiy press. Atlantic Highland.

30. Radhakrishnan S (1997) Introduction on the Principal Upanishads. Harpcollins Noida, India.

31. Sells M (1994) Mystical Languages of Unsaying. The University of Chicago Press, Chicago.

32. Shaygan, Darioush (1383) Religions and Schools of India. Tehran, Amir kabir. Publishing.

33. Shaygan, Darioush (1392) Indian customs and Islami Mysticism. Farzan publishing, Tehran.

34. Shymel, An Mary (1370) The Dignity of Shams. Translator: Lahooti. Elmi publishing. Tehran.

35. Smart N (1967) Indian Philosophy .the Encyclopedia of Philosophy. Paul E (Ed.), Macmillan Company. New York.

36. Stice VT (1379) Mysticism and Philosophy. Translator: Khoramshahi. Soroosh Tehran.

37. Radhakrishnan S (1994) The Principal upanisads, Edited with introduction text; Translation and notes by $\mathrm{S}$ radha Kraishnan, Humunitiy press, Atlantic Highland.

38. Barth A (2000) The Religions of India. Roultedge.

39. James W (1985) The varieties of religious experience. Modern library Inc. New York. 